\title{
PENGARUH VOCABULARY PREPARATION UNTUK PENINGKATAN KEMAMPUAN PEMAHAMAN LISTENING
}

\author{
Laila Rochmawati
}

Politeknik Penerbangan Surabaya

Jl. Jemur Andayani I, No. 73 Surabaya 60236

Email : lailaharun@gmail.com

\begin{abstract}
ABSTRAK
Artikel ini berkaitan dengan penelitian tentang pengaruh vocabulary preparation terhadap kemampuan pemahaman mendengarkan pada kinerja kosakata L2 peserta didik di poltekbang Surabaya. Para peserta dibagi menjadi tiga kelompok dimana mereka diberi tiga waktu persiapan yang berbeda untuk mempelajari kosakata baru yang akan diperdengarkan dalam kegiatan pemahaman listening. Instrumen yang digunakan adalah tes kosakata dan tes pemahaman listening. Hasil menunjukkan bahwasanya terdapat perbedaan yang signifikan dalam tes kosakata tetapi tidak dalam tes pemahaman listening. Tes kosakata dan pemahaman listening yang konsisten menunjukkan bahwa semakin banyak waktu persiapan mereka memiliki, skor yang lebih tinggi yang mereka capai.

Keyword: vocabulary preparation, kosakata L2, listening
\end{abstract}

\section{PENDAHULUAN}

Memahami suatu percakapan dalam bahasa inggris bukanlah sesuatu hal yang mudah bagi peserta didik EFL, ini dikarenakan karena bahasa pertama yang mendominasi mereka bukanlah bahasa inggris. Meraka harus belajar bagaimana cara mendengarkan secara luas dalam proses pembelajaran formal di dalam kelas. Bahkan ketika mereka akan mengambil tes listening di kelas, peserta didik biasanya dihadapkan dengan sejumlah kesulitan, yaitu kosakata yang terbatas, pengetahuan terkait topik yang belum dikenal, kecepatan bicara yang cepat dalam recording, aksen yang sulit untuk dipahami, dan waktu mendengarkan yang hanya sekali, konsentrasi hanya mendengar beberapa nama saja. Di antara faktor-faktor ini, kurangnya pengetahuan kosakata tampaknya menyebabkan kekhawatiran terbesar bagi pelajar EFL (Boyle, 1984; Chang, 2005; Chang and Read, 2006) dan karena alasan ini, menjadi hal yang biasa bahwasanya sebelum melakukan tes listening kita melakukan vocabulary preparation. Menyediakan kegiatan pra-tugas bagi peserta tes sehingga dapat meningkatkan kepercayaan diri mereka dan bisa membuat mereka tidak terbebani dengan tugas listening mereka. Kegiatan pra-tugas telah diuji dan ditunjukkan untuk membantu kelancaran dan kompleksitas dalam kinerja narasi lisan (Ellis, 1987; Crookes, 1989; Robinson et al.,1995; Foster and Skehan, 1996; Robinson, 2001) dengan kemampuan menulis (Kroll, 1990; Ellis and Yuan, 2004). Kegiatan semacam itu dapat membuat tugas lebih produktif (Willis, 1996), dan dapat mengurangi beban kognitif dan beban proses pembelajaran (Foster dan Skehan, 1996; Skehan, 1996). Alasan lain untuk menggunakan aktivitas pra-tugas adalah memperkenalkan bahasa baru, memobilisasi bahasa, mendaur ulang bahasa, dan meringankan beban pemrosesan (Skehan, 1998). Tiga jenis kegiatan utama pra-tugas diusulkan oleh Skehan (1998): pengajaran, peningkatan kesadaran, dan perencanaan. Pembelajaran vocabulary berkaitan dengan pengenalan bahasa baru ke sistem antarbahasa atau merestrukturisasi sistem yang mendasarinya. Kegiatan peningkatan kesadaran melibatkan diskusi pra-tugas dan paparan materi yang relevan dengan tugas terkait. Perencanaan melibatkan masalah waktu. Durasi waktu yang berbeda untuk perencanaan mempengaruhi penampilan siswa, biasanya lebih pada tugas yang sulit daripada yang lebih 
mudah. Beberapa studi tentang pengaruh waktu perencanaan pada output bahasa kedua menunjukkan bahwa waktu perencanaan mempengaruhi output ke tingkat yang signifikan dalam hal kelancaran, kompleksitas dan akurasi (Ellis, 1987; Ellis and Yuan, 2004; Foster and Skehan, 1996; Skehan and Foster, 1997,1999; Wigglesworth, 1997). Hasil yang menggembirakan ini berasal dari hasil studi keterampilan, baik keterampilan reseptif, misalnya listening, akan memperoleh hasil yang serupa dan akan dieksplorasi dalam penelitian ini.

\section{METODE PENELITIAN}

Peserta terdiri dari 72 taruna poltekbang Surabaya tingkat satu semester satu, yang berusia 18-21 tahun, ambil bagian dalam penelitian ini. Para peserta berasal dari tiga kelas dari course komunikasi penerbangan angkatan 4 A dan 4 B dan lalu lintas udara angkatan 11 A . Pada awal tahun ajaran baru mereka semua diberikan tes pendengaran TOEIC, yang mencerminkan bahwa sekitar dua pertiga berada di tingkat awal yang tinggi dan sepertiga pada tingkat menengah yang rendah. Hasil tes TOEIC dari ANOVA mengungkapkan tidak ada perbedaan yang signifikan di antara tiga kelompok eksperimen, $\mathrm{F}(2.115)=1,97, \mathrm{p}=$ 0,144 (dengan set alfa pada 0,05) (lihat Lampiran A untuk statistik deskriptif). Pada saat penelitian sedang dilakukan, mereka telah dilatih untuk mendengarkan cerita dan mencatat. Menurut skor tes TOEIC (skor mentah> 40) dan nilai akhir mereka dari semester sebelumnya (> 80), para peserta diklasifikasikan menjadi dua tingkat: lebih maju (tinggi) dan kurang maju (rendah). A kelompok dengan waktu persiapan 1 minggu; B kelompok dengan satu hari waktu persiapan; $\mathrm{C}$ - grup dengan 30 menit waktu persiapan.

Table 1. Descriptive statistics for TOEIC listening scores across groups

(raw scores)

\begin{tabular}{cccccc}
\hline Group & N & M & SD & min & max \\
\hline A & 24 & 35.20 & 7.25 & 18 & 53 \\
B & 24 & 36.13 & 7.22 & 25 & 56 \\
C & 24 & 38.74 & 7.49 & 26 & 61 \\
Total & 72 & 36.37 & 7.46 & 18 & 61 \\
\hline
\end{tabular}

\section{Desain penelitian}

Ada tiga kelompok eksperimental (Grup A - C ). Grup A diberikan daftar kosakata seminggu sebelum tes LC, grup B satu hari sebelumnya dan grup C tidak diberikan materi apa pun untuk belajar di rumah, tetapi mereka mempelajari kosakata di kelas selama 30 menit dan diizinkan untuk diskusi, dan ini berfungsi sebagai landasan dasar di seluruh kelompok. Untuk menyelidiki dampak dari persiapan kosakata pada pemahaman listening mereka, para peserta diberitahu bahwa vocabulary dalam daftar akan muncul dalam teks-teks dari tes. Desain penelitian ditetapkan dalam table 2 .

Tabel 2. Research design

\begin{tabular}{llll}
\hline Kelompok & Experimental groups & \\
\hline & A & B & C \\
\hline Waktu Persiapan & 1 minggu & 1 hari & 30 menit \\
\hline Jumlah peserta & 24 & 24 & 24 \\
\hline
\end{tabular}




\section{Tes Listening}

Teks mendengarkan yang digunakan dalam penelitian ini adalah 306 kata cerita pendek yang dipilih dari aviation training center dengan judul problems with passengers. Teks ini dipilih karena sesuai dengan karakteristik pembelajaran mata kuliah yang mereka ambil.

\section{Instrumen}

Instrumen yang digunakan dalam penelitian ini adalah tes vocabulary dan tes listening comprehension. Detail masing-masing instrumen adalah sebagai berikut:

1. Tes kosakata: Berdasarkan daftar kosakata, 33 kata dipilih untuk menguji apakah peserta telah mempelajari kata-kata.

2. Tes listening comprehension: Tes pemahaman mendengarkan yang berisi 30 item dikonstruksi untuk mengukur pemahaman peserta terhadap cerita. Seluruh tes berisi tiga format tes yang sudah akrab bagi siswa: pertanyaan pilihan ganda, mengisi ganjil, dan jawaban singkat.

\section{Materials}

Daftar kosakata berisi 25 kata dari cerita; 8 kata benda, 9 kata kerja, 3 kata benda yang tepat dan 5 kata sifat. Untuk menghindari variasi pendapat tentang kesulitan kata-kata antara peneliti dan peserta tes dan antara siswa tingkat rendah dan tinggi, kata-kata yang dipilih diperoleh dari 6 siswa (3 dengan tingkat kemahiran rendah dan 3 dengan tingkat kemahiran tinggi) yang mengajukan diri dalam studi percontohan di tahap awal penelitian, tetapi mereka bukan siswa dalam penelitian ini. Kata-kata yang dipilih oleh relawan digunakan sebagai referensi saja, dan akhirnya peneliti sendiri yang memutuskan kata-kata yang dipakai dalam daftar.

\section{Prosedur}

Grup A diberikan daftar vocabulary seminggu sebelum ujian, dan Grup B, sehari sebelum ujian. Grup C diberikan daftar kosakata 30 menit sebelum tes diberikan, kemudian daftar dikumpulkan. Para peserta pertama kali diberikan tes vocabulary, kemudian tes listening comprehension.

\section{HASIL PENELITIAN}

\section{Analisis Data}

SPSS versi 22 untuk Windows digunakan untuk analisis data. Analisis univariat menggunakan model linier umum (GLM) dilakukan untuk mengevaluasi dampak persiapan kosakata pada pengetahuan kosakata peserta didik, pemahaman mendengarkan, skor yang diperoleh dari tes. Dua variabel independen tersebut adalah Grup A - C (tiga waktu persiapan yang berbeda) dan kemampuan mendengarkan siswa listening proficiency (LP - dua level: tinggi dan rendah).

\section{Hasil dan diskusi \\ Hasil}

Apakah waktu persiapan yang berbeda membuat perbedaan bagi kinerja pebelajar dalam pengetahuan vocabulary atau listening comprehension secara keseluruhan? Pertanyaan ini diselidiki dengan membandingkan hasil tes vocabulary dan tes listening comprehension. Tabel 3 menyajikan hasil tes keseluruhan dan itu menunjukkan bahwa siswa di seluruh kelompok mendapat skor lebih tinggi pada kosakata daripada tes pemahaman mendengarkan. Dalam tes kosakata, rata-rata, Grup A menjawab 76\% dengan benar, lebih 
tinggi dari Grup B dengan 65\%, dan Grup C pada 63\%; Namun, perbedaan antara Grup B dan $\mathrm{C}$ hanya sedikit yaitu dua persen.

Table 3. Test results

\begin{tabular}{llll}
\hline Tes & Group A & Group B & Group C \\
\hline $\begin{array}{l}\text { Vocabulary test } \\
\begin{array}{l}\text { Listening } \\
\text { comprehension }\end{array}\end{array}$ & $13.68(3.78) 76 \%$ & $11.70(3.78) 65 \%$ & $11.34(3.96) 63 \%$ \\
\hline
\end{tabular}

Dalam tes pemahaman mendengarkan, Grup A mendapat nilai tertinggi, 59\%, diikuti oleh Grup B, 56\% dan Grup C, 54\%. Meskipun perbedaan di antara ketiga kelompok itu minimal, skor menunjukkan pola yang konsisten: semakin lama waktu persiapan, semakin tinggi skor yang mereka capai. Tabel 3 menunjukkan dampak keseluruhan persiapan kosakata terhadap kinerja peserta didik. Untuk mengungkap apakah ada perbedaan yang signifikan, analisis variansi univariat GLM dilakukan. Variabel dependen adalah skor tes vocabulary dan variabel independen adalah kelompok $\mathrm{ABC}$ dengan tiga waktu persiapan yang berbeda dan listening proficiency (dua tingkat). Ringkasan dari GLM analisis pada tes vocabulary disajikan pada Tabel 4. Efek utama yang signifikan ditemukan pada kelompok, F (2.115) = $6.61, \mathrm{p}=.002$, dan kemampuan mendengarkan (LP), $\mathrm{F}(1,116)=4,01, \mathrm{p}=.048$. Tidak ada efek interaksi yang signifikan yang ditemukan. Pengaruh pada grup adalah antara sedang dan besar (.10). Menurut pedoman Cohen (1988), ukuran efek 0,06 sedang dan 0,14 besar. Meskipun efek utama ditemukan untuk LP, ukuran efeknya cukup kecil $(0,03)$ dan kekuatan yang diamati hanya 0,51 . Oleh karena itu, LP siswa memainkan peran yang kurang penting daripada jumlah waktu persiapan untuk hasil tes kosa kata. Tabel 5 menyajikan ringkasan analisis GLM pada tes LC. Dua variabel independen sama seperti pada bagian sebelumnya, tetapi variabel dependen adalah skor LC. Koefisien reliabilitas (Cronbach a) adalah 0,73 untuk tes LC, yang dapat dianggap memuaskan untuk tes yang dibuat pengajar sebanyak 29 item. Faktor penting yang mungkin mengurangi keandalan adalah rentang LP yang terbatas di antara para peserta. Efek utama ditemukan untuk kedua Grup, F $(2,116)=3,34$, p <.05, dan LP, F $(1,117)=28,67, \mathrm{p}<.000$. Namun, ukuran efek untuk Grup kecil, hanya 0,05, tetapi besar untuk LP (.20). Hasilnya menunjukkan bahwa LC peserta lebih bergantung pada LP mereka daripada pada jumlah waktu persiapan dengan kosakata, dan LC tidak dapat ditingkatkan hanya dengan membiasakan kosakata.

Table 4. Results of the effects of preparation time on learners' vocabulary performance

\begin{tabular}{llllllll}
\hline Source & SS & d.f. & MS & F & Sig. & $\begin{array}{l}\text { Effect size (eta } \\
\text { squared) }\end{array}$ & $\begin{array}{l}\text { Observed } \\
\text { power }\end{array}$ \\
\hline Group & 183.90 & 2 & 91.95 & 6.61 & 002 & 0.10 & .91 \\
LP & 55.73 & 1 & 55.74 & 4.01 & .048 & 0.03 & .51 \\
Group · LP & 8.24 & 2 & 4.12 & .30 & .744 & 0.00 & .10 \\
Error & 1530.42 & 79 & 13.91 & & & & \\
Total & 18854.0 & 79 & & & & & \\
Corrected total & 1763.79 & 79 & & & & & \\
\hline
\end{tabular}


Table 5. Results of the effects of preparation time on learners' listening comprehension

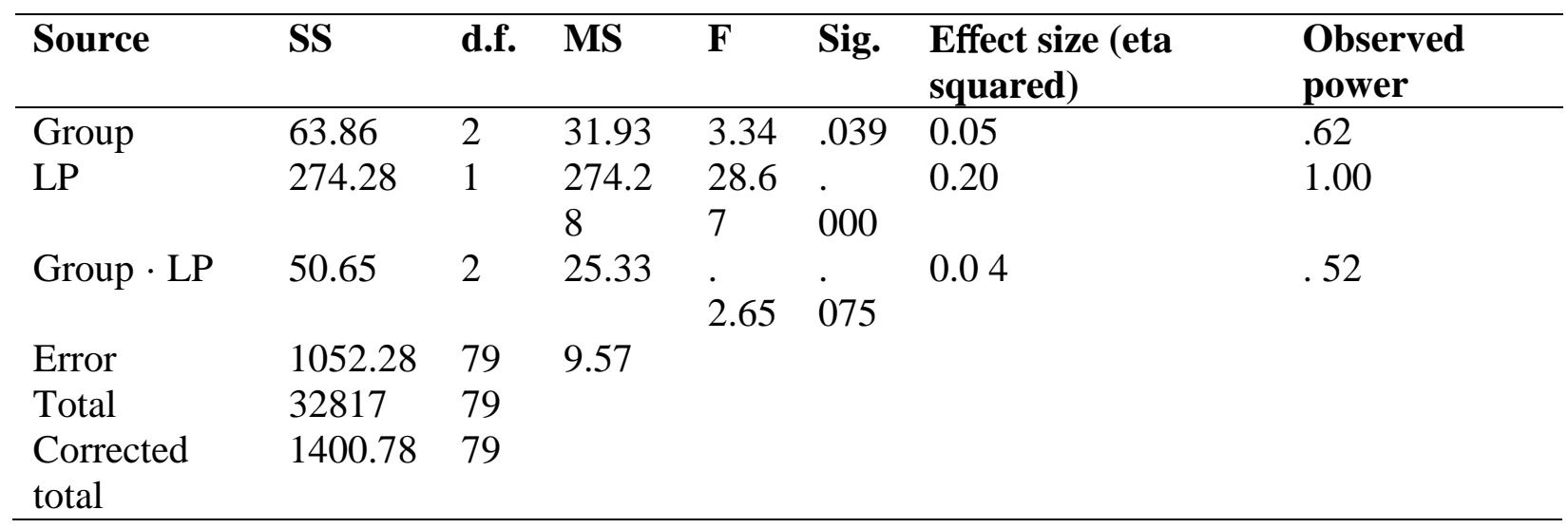

Penemuan dari penelitian ini adalah bahwa kinerja keseluruhan siswa menunjukkan pola konsisten waktu persiapan yang lebih lama, skor yang lebih tinggi tercapai, namun perbedaannya antara kelompok hanya signifikan dalam pemahaman kosakata tidak dalam pemahaman cerita. Grup A, yang memiliki waktu 1 minggu untuk menyiapkan kosakata, mendapat nilai yang lebih tinggi secara signifikan daripada dua grup lainnya, tetapi tidak ada perbedaan mencolok antara Grup B dan C.

\section{KESIMPULAN}

Penelitian ini mencoba untuk menguji dampak dari tiga variasi waktu persiapan yang berbeda dalam kosakata yang berbeda pada kinerja LC peserta L2. Persiapan kosa kata bisa sangat berguna dalam tes kelas karena meningkatkan kepercayaan siswa dan meningkatkan kesediaan mereka untuk menyelesaikan tugas. Dari hasil penelitian ini, siswa diberikan teks kosakata untuk meningkatkan pemahaman siswa L2, alasannya adalah bahwa LC tidak dapat ditingkatkan hanya dengan mengetahui kosakata. Namun, poin utamanya bukanlah hasil tes tetapi kepercayaan peserta dan penggunaan strategi terhadap tugas tes yang diberikan. Implikasi penemuan ini adalah untuk pengembangan metode mengajar listening di ruang kelas bahasa asing.

Semakin banyak waktu untuk belajar tidak menjamin pemahaman yang lebih baik atau tingkat kepercayaan yang lebih tinggi secara signifikan. Tingkat kepercayaan untuk siswa LP rendah di Grup A dan C sebanding, yang menyiratkan bahwa memberikan kesempatan untuk belajar bersama dapat sangat meningkatkan kepercayaan siswa dan efeknya dapat sebaik memberi siswa waktu yang banyak untuk mempersiapkan tes. Menurut Dansereau (1988), pembelajaran kooperatif dapat mempromosikan pemrosesan informasi aktif dan meningkatkan motivasi dalam peserta. Oleh karena itu, belajar di kelas dan mendorong belajar kelompok mungkin merupakan pendekatan yang baik untuk mendorong pembelajaran berlangsung.

Penelitian ini menguji dampak waktu persiapan kosa kata pada pendengaran L2. Namun, satu batasan perlu ditunjukkan: cukup sulit untuk mengendalikan jumlah waktu yang digunakan para siswa untuk persiapan. Meskipun siswa yang diberikan persiapan satu minggu tidak mengeluh tentang kurangnya waktu, tidak diketahui berapa banyak waktu yang mereka habiskan untuk persiapan. Dengan mempertimbangkan keterbatasan ini, saran untuk penelitian masa depan adalah bahwa untuk lebih mengontrol waktu yang ditentukan, studi kelas berjangka waktu akan meningkatkan pemahaman kita tentang bagaimana waktu persiapan kosa kata mempengaruhi L2 peserta didik 'LC. 


\section{DAFTAR PUSTAKA}

Berne, J.E., 1995. How does varying pre-listening activities affect second language listening comprehension? Hispania 78, 316-329.

Boyle, J.P., 1984. Factors affecting listening comprehension. English Language Teaching Journal 38, 34-38.

Buck, G., 2001. Assessing Listening. Cambridge University Press, Cambridge.

Chang, C.-S., 2004. An investigation of listening support on test-takers' performance in EFL listening tests. In: Selected Papers from the Thirteenth International Symposium on English Teaching. Crane, Taipei, Taiwan,pp. 239-249.

Chang, C.-S., 2005. The effect of lexical support in EFL listening comprehension tests. The Proceedings of the 22nd International Conference on English Teaching and Learning in the Republic of China. Crane, Taipei,Taiwan, pp. 13-27.

Cohen, J., 1988. Statistical Power Analysis for the Behavioral Sciences. Lawrence Erlbaum, Hillsdale, NJ.

Crookes, G., 1989. Planning and interlanguage variation. Studies in Second Language Acquisition 11, 367-383.

Dansereau, D.F., 1988. Cooperative learning strategies. In: Weisntein, C.E., Goetz, E.T., Alexander, P.A. (Eds.), Learning and Study Strategies: Issues in Assessment, . In: Instruction, and Evaluation. Academic Press, New York, pp. 103-120.

Elkhafaifi, H., 2005. The effect of prelistening activities on listening comprehension in Arabic learners. Foreign Language Annals 38, 505-513.

Ellis, R., 1987. Interlanguage variability in narrative discourse: style shifting and use of the past tense. Studies in Second Language Acquisition 9, 1-20.

Foster, P., Skehan, P., 1996. The influence of planning and task type on second language performance. Studies in Second Language Acquisition 18, 299-323.

Gathercole, S., Baddeley, A.D., 1989. Evaluation of the role of phonological STM in the development of vocabulary in children: a longitudinal study. Journal of Memory and Language 28, 200-213.

Gu, Y., Johnson, R., 1996. Vocabulary learning strategies and language learning outcomes. Language Learning 46, 643-679.

Hsieh, L.T., 1999. The effects of pre-reading vocabulary instruction and cultural background knowledge activation on Chinese junior college fourth-year students' EFL reading. Proceedings of the Sixteenth Conference on English Teaching and Learning in the Republic of China. Crane, Taipei, Taiwan, pp. 227-239. 